Article

\title{
Impacts of Sea Level Rise and Groundwater Extraction Scenarios on Fresh Groundwater Resources in the Nile Delta Governorates, Egypt
}

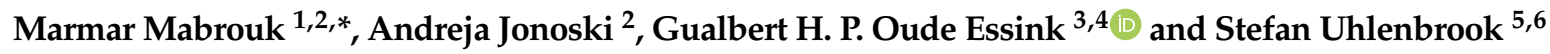 \\ 1 Ministry of Water Resources and Irrigation, Nile Water Sector, P.O. Box 11471, 11728 Cairo, Egypt \\ 2 IHE Delft, Department of Integrated Water Systems and Governance, P.O. Box 3015, 2601 DA Delft, \\ The Netherlands; a.jonoski@un-ihe.org \\ 3 Deltares, Unit of Subsurface and Groundwater Systems, Daltonlaan 600, 3584 BK Utrecht, The Netherlands; \\ gualbert.oudeessink@deltares.nl \\ 4 Department of Physical Geography, Utrecht University, Princetonlaan 8a, 3584 CB Utrecht, The Netherlands \\ 5 Water Resources Section, Delft University of Technology, P.O. Box 5048, 2600 GA Delft, The Netherlands; \\ s.uhlenbrook@un-ihe.org \\ 6 World Water Assessment Programme, UNESCO, Villa La Colombella, Colombella Alta, 06134 Perugia, Italy \\ * Correspondence: marmarbadr80@yahoo.com; Tel.: +20-1129353635 or +31-619741794
}

Received: 21 August 2018; Accepted: 9 November 2018; Published: 20 November 2018

check for updates

\begin{abstract}
As Egypt's population increases, the demand for fresh groundwater extraction will intensify. Consequently, the groundwater quality will deteriorate, including an increase in salinization. On the other hand, salinization caused by saltwater intrusion in the coastal Nile Delta Aquifer (NDA) is also threatening the groundwater resources. The aim of this article is to assess the situation in 2010 (since this is when most data is sufficiently available) regarding the available fresh groundwater resources and to evaluate future salinization in the NDA using a 3D variable-density groundwater flow model coupled with salt transport that was developed with SEAWAT. This is achieved by examining six future scenarios that combine two driving forces: increased extraction and sea level rise (SLR). Given the prognosis of the intergovernmental panel on climate change (IPCC), the scenarios are used to assess the impact of groundwater extraction versus SLR on the seawater intrusion in the Delta and evaluate their contributions to increased groundwater salinization. The results show that groundwater extraction has a greater impact on salinization of the NDA than SLR, while the two factors combined cause the largest reduction of available fresh groundwater resources. The significant findings of this research are the determination of the groundwater volumes of fresh water, brackish, light brackish and saline water in the NDA as a whole and in each governorate and the identification of the governorates that are most vulnerable to salinization. It is highly recommended that the results of this analysis are considered in future mitigation and/or adaptation plans.
\end{abstract}

Keywords: saltwater intrusion; sea level rise; Nile Delta aquifer; fresh groundwater volume; extraction; Nile Delta governorates

\section{Introduction}

The Nile Delta in Egypt, along with its fringes, covers an area of approximately $30,000 \mathrm{~km}^{2}$ [1]. It is occupied by the most populated governorates in Egypt. About $60 \%$ of Egypt's population lives in the Nile Delta region. Agriculture activities are predominant in the region due to the nature of the soil and the presence of an irrigation system [2]. The Nile Delta aquifer (NDA) is a vast aquifer located between Cairo and the Mediterranean Sea [3]. The NDA was formed by Quaternary deposits with a wide variety of hydrogeological characteristics and spatially varying salinity levels [4]. These deposits 
represent different aggradation and degradation phases that were usually accompanied by sea level changes [5]. Recent years have brought scientific evidence of increased groundwater salinization in NDA, predominantly driven by increased groundwater extraction [4].

Salinity in groundwater is a major quality hazard that limits its usage and affects the productivity of agricultural areas that depend on irrigation from groundwater wells [6]. The nature and properties of salinity were reviewed with a view to its management in Reference [7]. In coastal aquifers, such as the NDA, the salinity in groundwater is influenced by human interventions through excessive groundwater extraction, while saltwater intrusion (SWI) induced by sea-level rise (SLR) is also anticipated [8].

In north Kuwait, a freshwater aquifer polluted by saline seawater was modelled using a 3D numerical model [9]. The researchers declared that solute transport modelling has become a significant tool for analysing the groundwater quality, as it can provide insight into past and present behaviour and predict water quality management scenarios. It was also highlighted that climate change is likely to lead to multiple stresses in the groundwater sector [10]. This research emphasized the need for the development of management models that simulate SWI in aquifers and the assessment of future compound groundwater challenges. Open challenges and uncertainties regarding the influences of climate change in coastal aquifers were identified in Reference [11]. In Kish Island, Iran, the combined impacts of SLR with the associated land inundation and climate-induced variation of natural recharge to the aquifer system were analysed [12]. The results showed that the combined impact of SLR-induced land inundation and recharge rate variation is more significant compared to SLR impacts alone. A review of SLR impacts on SWI in coastal aquifers together with other factors, such as recharge rate variation, land inundation due to SLR, aquifer bed slope variation and changing landward boundary conditions [13], concluded that the impacts of these combined factors on SWI need to be further investigated. The NDA, like other coastal aquifers, is subjected to salinization threats.

Regarding NDA, [14] focused on a stretch between Ras El Bar and Gamasa along Egypt's Northern coast. They found that the effect of SLR will be salinization of the NDA and they proposed artificial recharge through injection wells as a mitigation strategy. Further analysis of the impacts of SLR on SWI in the NDA was done by [15]. They concluded that large coastal areas will be totally submerged by SLR and that the shoreline will be shifted several kilometres inland. The research utilized a two-dimensional FEFLOW model [16]. This modelling study used many assumptions due to a lack of available data. A 3D modelling approach was used by [17] to identify the effect of the increasing SLR, decreasing surface water level and increasing groundwater extraction on SWI in NDA. They found that under a combined scenario of increased groundwater extraction rates by $100 \%$, an increased SLR by $100 \mathrm{~cm}$ and a decreased surface water level by $100 \mathrm{~cm}$ would cause the SWI to extend $79.5 \mathrm{~km}$ in the west and $92.75 \mathrm{~km}$ in the east from the shoreline by 2100 .

While these studies have addressed some aspects of the SWI problem in the NDA, research covering the whole Nile Delta using 3D modelling to predict future scenarios of SWI has been quite limited. This approach is used in the current article to analyse the combined impact of SLR and excessive groundwater extraction in the NDA. Unlike previous studies that mainly presented the landside shift of the shore boundary and the dispersion zone due to SLR, the advantage of using a 3D model for this analysis is that it allows the determination of the full spatial distribution of SWI and the analysis of volumes of available fresh groundwater under different future scenarios. This enables a comparative analysis of the available volumes of different groundwater types (fresh water, light brackish, brackish and saline water) under different scenarios for the whole NDA. Moreover, for the first time, the volumes of each groundwater types are analysed per Nile Delta governorate (administrative regions in Egypt), according to their location in the Nile Delta. This may lead to more location-driven recommendations for mitigation and adaptation measures that could be implemented at the governorate level.

To carry out this analysis, a 3D variable-density groundwater flow model coupled with salt transport developed using the SEAWAT modelling system [18]. Because this is a regional model that is focused on freshwater resources in the NDA, it does not consider the dynamic coastline or the local 
coastal flooding processes. Thus, it is assumed that the horizontal position of the hydraulic head boundary at the coast is fixed. The model was calibrated by the groundwater salinity conditions in 2010, the year that serves as a baseline model and reference condition for future scenarios because most of the data required for a reliable analysis is sufficiently available for that year. This analysis proposes six scenarios to assess the impact of SLR versus groundwater extraction in the Nile Delta and determines which factor is causing increased groundwater salinization. The values assumed for the SLR and groundwater extraction rates are based on IPCC reports [19] and the Egyptian National Plan, as will be discussed later, in detail. In the first scenario (Sc.1), the model run until the year 2500 with no increase in SLR or groundwater extraction (same values as in 2010) to test the influence of time only on the complex groundwater system in NDA (as SLR will not stop after 2100) and to investigate the natural autonomous salinization process [20]. The comparative analysis for the remaining five scenarios is carried out by running the model until the year 2100 with varying SLR and groundwater extraction rates. This analysis leads to a proposal of future groundwater extraction levels for different Nile Delta governorates, which can be considered in future plans for the overall development of groundwater resources in the area.

\section{Study Area}

The study area is the Nile Delta in the Northern part of Egypt (Figure 1). It is the most fertile region in Egypt and is surrounded by highly arid desert. The Nile Delta begins approximately $20 \mathrm{~km}$ north of the Cairo governorate in the south and extends to the Mediterranean Sea in the north, covering an area of about $30 \times 10^{3} \mathrm{~km}^{2}$. In the west, it is bounded by the Alexandria governorate and in the east, by Port Said. The Nile Delta contains 11 governorates that have economic, cultural and agricultural importance to Egypt. The locations and the names of the Nile Delta governorates are presented in Figure 1.

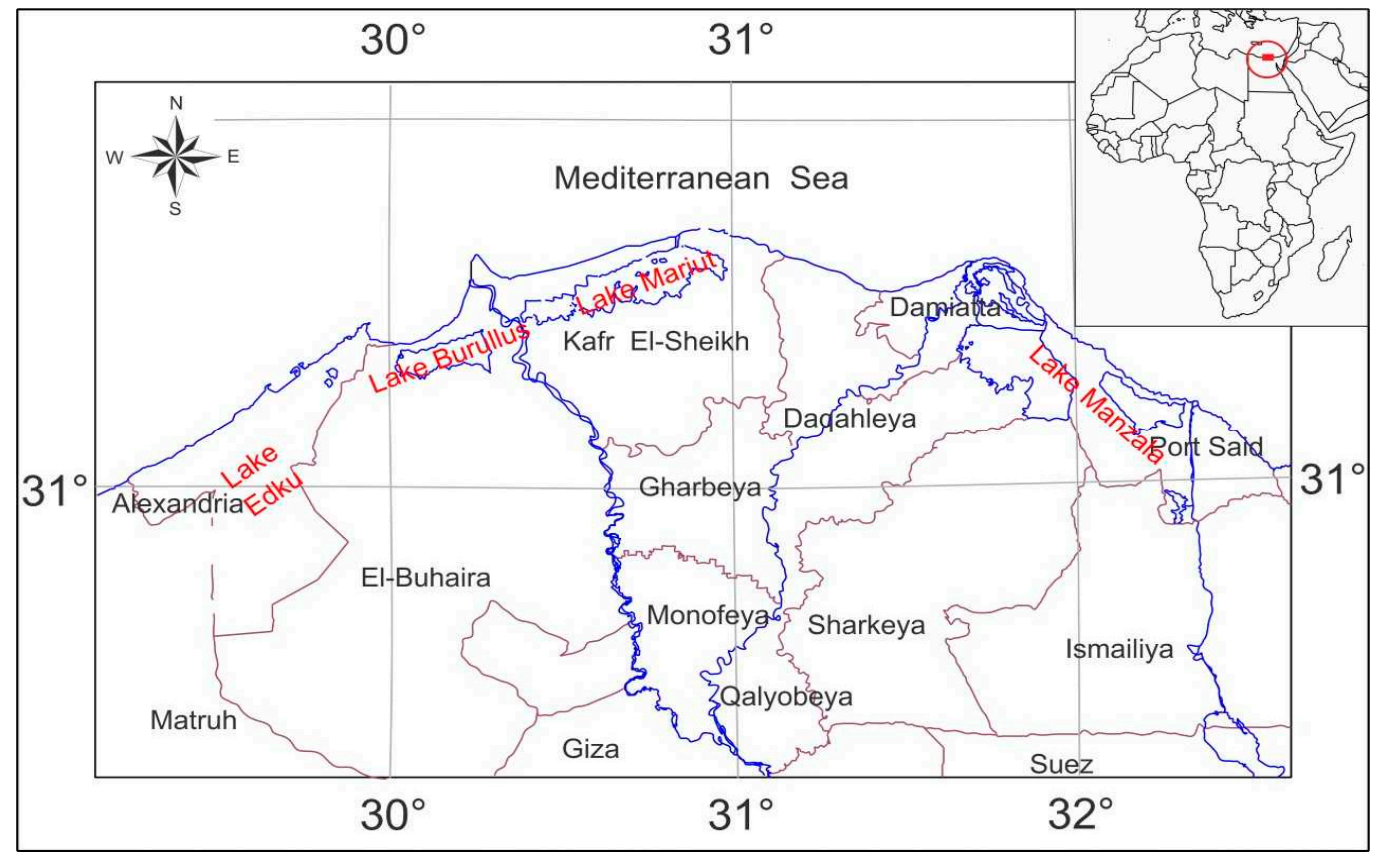

Figure 1. The study area of the Nile Delta.

The NDA is a large, semi-confined aquifer. It has Quaternary deposits that are classified into Holocene and Pleistocene strata [21]. The average thickness of the Holocene is $25 \mathrm{~m}$. It reaches around $50 \mathrm{~m}$ close to the sea and vanishes towards delta fringes in the South. The Pleistocene is the main aquifer of the Nile Delta [22]. Its thickness varies from 200 in the south to $1000 \mathrm{~m}$ in the north. It is 
composed of sand and gravel with occasional clay lenses and it is underlain by a Pliocene layer composed of marine limestone and shale [2,3,21].

\section{Method}

\subsection{Numerical Model}

A 3D variable-density groundwater flow and coupled salt transport model for the NDA was developed using SEAWAT [18]. The model captures the situation in the year 2010, since for this year, most data is available. It includes a large amount of different types of hydrogeological data collected from several sectors and research institutions within the Egyptian Ministry of Water Resources and Irrigation (MWRI).

The model domain is discretized using 100 rows and 150 columns horizontally (grid cell sizes $2 \times 2 \mathrm{~km}^{2}$ ) and 21 modelling layers in the vertical direction, which enables sufficiently detailed simulations of salinity variations to be carried out under different conditions. The Mediterranean Sea is represented as a constant head and constant salinity boundary. The Suez Canal in the east is considered to be a no-flow boundary. The last (deepest) modelling layer of the 21 layers represents the impermeable Pliocene, which underlays the Pleistocene aquifer. This last modelling layer of the 21 layers also contains salinity sources arising from the dissolution of marine deposits present in the Pliocene [23]. The first (shallowest) modelling layer of the 21 layers represents the Holocene layer which is specified as having a constant horizontal hydraulic conductivity of $0.25 \mathrm{~m} /$ day. For the next 19 modelling layers, the horizontal hydraulic conductivity values vary from 15 to $150 \mathrm{~m} /$ day. The anisotropy of hydraulic conductivity is considered to be $10 \%$ [24]. The effective porosity for the Holocene is specified as having a constant value of $40 \%$ and it varies from $12 \%$ to $28 \%$ in the Pleistocene. The main source of recharge in the NDA is the excess irrigation water at the agricultural zones. This spatially varying recharge, together with spatially varying water levels and salinity concentrations in the main irrigation canals, was specified to the model to ensure proper characterization of the groundwater entering the modelling domain. The majority of canals have water with a maximum salinity of $0.3 \mathrm{~kg} / \mathrm{m}^{3}$ but in some locations, the salinity concentration reaches $0.65 \mathrm{~kg} / \mathrm{m}^{3}$ and this is even greater towards the Mediterranean. The overall groundwater extraction in 2010 was estimated to be about $4.9 \times 10^{9} \mathrm{~m}^{3} /$ year [4]. The wells are distributed according to their depth in the corresponding modelling layer.

The model was calibrated with observed salinity data coming from 155 observation wells. The calibration results provided a Root Mean Square Error (RMSE) of $0.2 \mathrm{~kg} / \mathrm{m}^{3}$. The absolute difference and the standard deviation between the simulated and the observed concentrations of the salinity in the Nile Delta were calculated to be $0.14 \mathrm{~kg} / \mathrm{m}^{3}$ and $0.11 \mathrm{~kg} / \mathrm{m}^{3}$, respectively. These values are quite small, so the developed model is considered to be sufficiently reliable for future analyses. Further details about the model development and calibration results are available in Reference [18].

\subsection{Future Scenarios}

One of the most important factors that control the development scenarios is the population growth rate, as it represents the main condition that directly affects future economic and social progress. According to the Egyptian Central Authority for Public Mobilization and Statistics [25], the population in Egypt has risen by approximately from 52 million capita in 1990 to 84 million capita in 2010. The growth rate decreased from $2.75 \%$ per year in the period $1976-1986$ to $2.02 \%$ per year during the period 1996-2006. The total population is predicted to reach 200 million capita in 2100 [26]. These population growth rates have led to corresponding increases in water needs for different water-consuming sectors. Moreover, in the future, the ascending gap between water demands and supply will result in more tension in negotiations over transboundary water projects on the Nile [27]. Groundwater extraction rates are likely to increase over time too, assuming the continuation of the almost linear trend of increase in groundwater extraction that follows population 
growth, as presented in Figure 2. This trend of increased groundwater extraction was constructed based on data collected from the past, starting in 1980 and then projecting until 2100 [4].

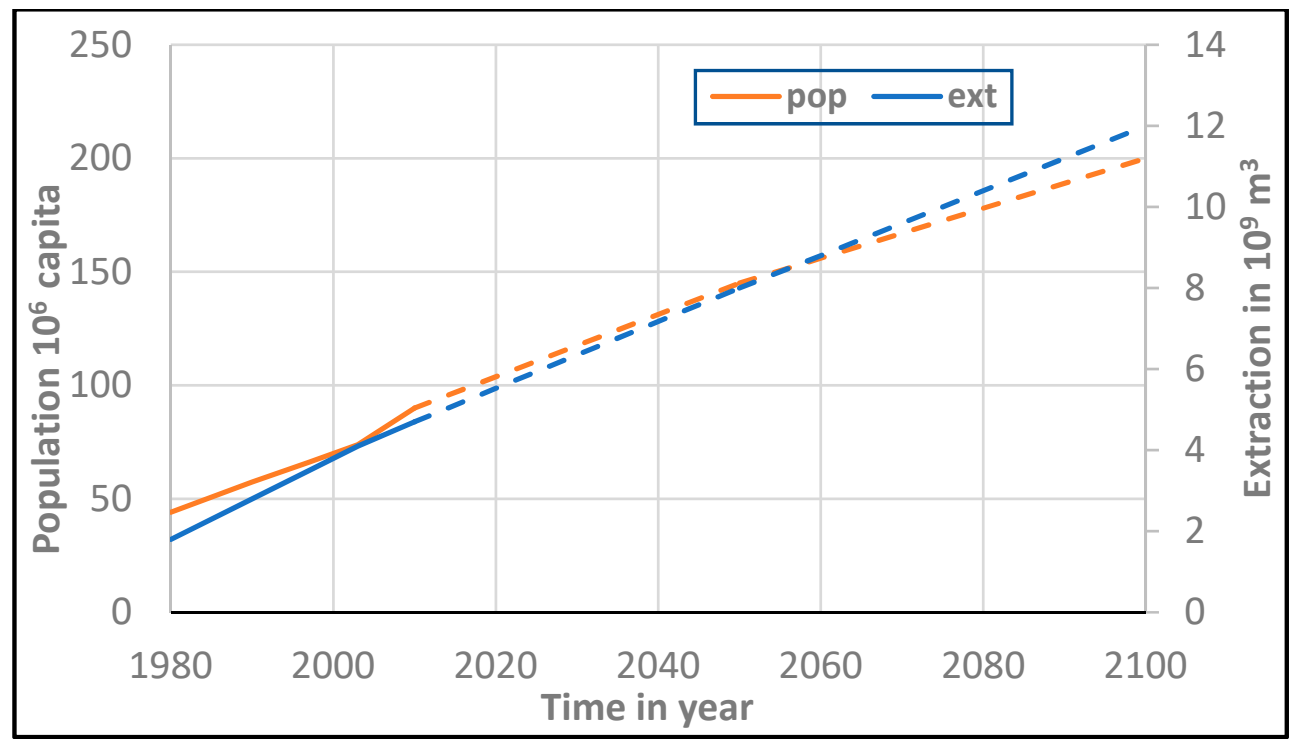

Figure 2. Population and groundwater extraction in the NDA as a function of time: current trend to 2010 (solid lines) and projections to 2100 (dashed lines) ([26]).

It is expected that climate change will substantially raise the sea level. The Intergovernmental Panel on Climate Change [19] emphasized the potential significance of SLR and predicted the global mean SLR by the year 2100 to be in the range $0.26-0.82 \mathrm{~m}$ compared to the earlier foreseen 0.18-0.59 m [28]. It was reported in Reference [29] that melting processes in Antarctica could contribute to a SLR of $1.05 \pm 0.3 \mathrm{~m}$ by 2100 under RCP 8.5. A probability density function of global SLR in 2100 was constructed in Reference [30]. It was found that the probability of having a SLR of more than $1.8 \mathrm{~m}$ is less than five percent, with a median probability of $0.8 \mathrm{~m}$. Their findings were based on process models combined with experts' opinions. They also stated that other lines of evidence are needed to justify any higher estimates of SLR for 2100. Recently, the probability density functions for extreme scenarios of global SLR in 2100 based on extreme mass loss from ice sheets using numerical simulations with a process-based model have been provided [31]. The median of their probability distribution was $0.73 \mathrm{~m}$. All these high SLRs will lead to severe impacts on SWI in coastal aquifers.

Future salinization of the groundwater resources in the NDA is a complex process and its prediction has a high degree of uncertainty. Consequently, different scenarios are proposed in this article to identify a wide spectrum of possible future adaptation strategies. These scenarios cover extreme projections to estimate future changes in the NDA in terms of the salinity distribution over the next hundred years as a function of SLR and groundwater extraction rates. Our estimated $12 \times 10^{9} \mathrm{~m}^{3}$ /year of groundwater extraction in 2100 (Table 1) is consistent with the projections in the future scenarios of the MWRI national plan. Regarding the SLR, the selected ranges in the future scenarios (see again Table 1) were chosen by considering the SLR reported in Reference [19] and the median of the probability density functions for extreme scenarios of global SLR in 2100 reported in the literature review stated above.

Sc.1 (long run) is different from all of the other proposed scenarios. There is neither a SLR, nor an increase in groundwater extraction (the same values as in 2010 are used). This scenario analyses the impact of time only (until 2500), focusing on the autonomous salinization process, as it is known that the salinity distribution in coastal groundwater systems lags behind the current boundary conditions $[20,32,33]$. Thus, this scenario is not used for comparisons with the other scenarios. The remaining five future scenarios are combinations of different SLR and groundwater extraction rates. 
Table 1. Future scenarios for sea-level rise (SLR) and groundwater extraction.

\begin{tabular}{|c|c|c|c|}
\hline Scenario (Sc.) & SLR (m) & Extraction $\left(10^{9} \mathrm{~m}^{3} /\right.$ Year $)$ & Time (Year) \\
\hline Reference & 0 & 4.9 & 2010 \\
\hline Sc.1 Long run & 0 & 4.9 & 2500 \\
\hline Sc. 2 Extreme & 1.5 & 12 & 2100 \\
\hline Sc.3 Moderate & 1 & 8 & 2100 \\
\hline Sc. 4 Restrictive & 0 & 4.9 & 2100 \\
\hline Sc.5 High ext. & 0 & 12 & 2100 \\
\hline Sc.6 High SLR & 1.5 & 4.9 & 2100 \\
\hline
\end{tabular}

Sc.2 (extreme) was selected to show the impact of the combined effect of a large SLR and extreme groundwater extraction on the NDA. The proposed population will reach 200 million per capita [26]. As the population growth continues with no birth control, a significant increase in groundwater extraction rate is expected $12 \times 10^{9} \mathrm{~m}^{3}$ /year to fulfil the high water demands (Figure 2). No control over groundwater extraction is assumed. In this scenario, the SLR is assumed to be $1.5 \mathrm{~m}$, which is also considered extreme based on the analyses in the literature review presented earlier.

Sc.3 (moderate) takes birth control and a reduced population growth rate into account. It is associated with moderate control of groundwater extraction. The population is estimated to be about 146 million capita [26]. According to the national future plan of MWRI in 2100, the government will have moderate investments in reclamation projects. The groundwater extraction will be $8 \times 10^{9} \mathrm{~m}^{3}$ /year. The government will control the unplanned groundwater extraction and benefit from the solar desalination plants that are planned to be constructed. A moderate SLR of $1 \mathrm{~m}$ is also assumed.

Sc.4 (restrictive) is a very optimistic scenario as it assumes that no increase in groundwater extraction will occur, due to control by high financial penalties for any non-authorized groundwater extraction. In this scenario, the government depends on water resources other than groundwater. This scenario was selected to show the results of completely prohibiting groundwater extraction. Also, it is assumed that there will be no SLR. In fact, this scenario has same conditions as Sc.1 (long run) but it is analysed until 2100.

In Sc.5 (high ext.), the government encourages investments and land reclamation which leads to a dramatic increase in groundwater extraction and hence, increases groundwater salinization. In this scenario, the groundwater extraction rates are proposed to reach again $12 \times 10^{9} \mathrm{~m}^{3} /$ year by 2100 . This scenario was selected to examine the impact of groundwater extraction alone, so the assumed SLR is $0 \mathrm{~m}$.

On the contrary, the objective of Sc.6 (high SLR) is to measure the impact of SLR only. The groundwater extraction rate is same as now (2010) and a SLR of only $1.5 \mathrm{~m}$ is assumed. Scenarios 5 and 6 help to identify which is the main driving factor in the SWI process: SLR or groundwater extraction.

All six scenarios consider that the Egyptian policy towards cooperation with the Nile basin countries will continue to be the same and consequently, water levels in canals and water use for agriculture will remain constant. The increase of groundwater extraction in different scenarios is without any spatial variation compared to 2010. This study analysed how NDA will develop in the future with current spatial distribution of wells. Each existing well field will gradually increase the groundwater extraction until 2100. Further studies may investigate different spatial distributions of groundwater extraction. The initial conditions of the model were taken from the calibrated model's results for 2010. The model was run for 90 years for scenarios 2, 3, 4, 5 and 6 to predict the future SWI in 2100. For Sc.1, the model was run for 490 years to predict the SWI in the year 2500. 


\section{Results and Discussion}

\subsection{The Whole Nile Delta}

The total volume of groundwater in NDA up to the hydrogeological base was estimated to be approximately $4050 \times 10^{9} \mathrm{~m}^{3}$ covering an area of approximately $30 \times 10^{3} \mathrm{~km}^{2}$. This agrees with Reference [15] who estimated the groundwater volume of NDA to be around $3600 \times 10^{9} \mathrm{~m}^{3}$ but with a smaller modelled area $\left(24 \times 10^{3} \mathrm{~km}^{2}\right)$. According to [34], groundwater can be classified into different types with respect to the salinity level. Fresh water has a salinity of $0-1 \mathrm{~kg} / \mathrm{m}^{3}$, light brackish has $1-5 \mathrm{~kg} / \mathrm{m}^{3}$, brackish has $5-30 \mathrm{~kg} / \mathrm{m}^{3}$ and saline water has salinity greater than $30 \mathrm{~kg} / \mathrm{m}^{3}$. Figure 3 shows the different proportions of the groundwater types in 2010, together with their spatial distribution within the Delta. Fresh water accounts for 37\%, light brackish 10\%, brackish $21 \%$ and saline water $32 \%$. The volume of total available fresh water is approximately $1290 \times 10^{9} \mathrm{~m}^{3}$ and the volume of light brackish water is about $421 \times 10^{9} \mathrm{~m}^{3}$. Table 2 provides estimates of the groundwater volume in $\times 10^{9} \mathrm{~m}^{3}$ occupied by the four groundwater types for the current conditions in 2010 and for the six analysed scenarios.

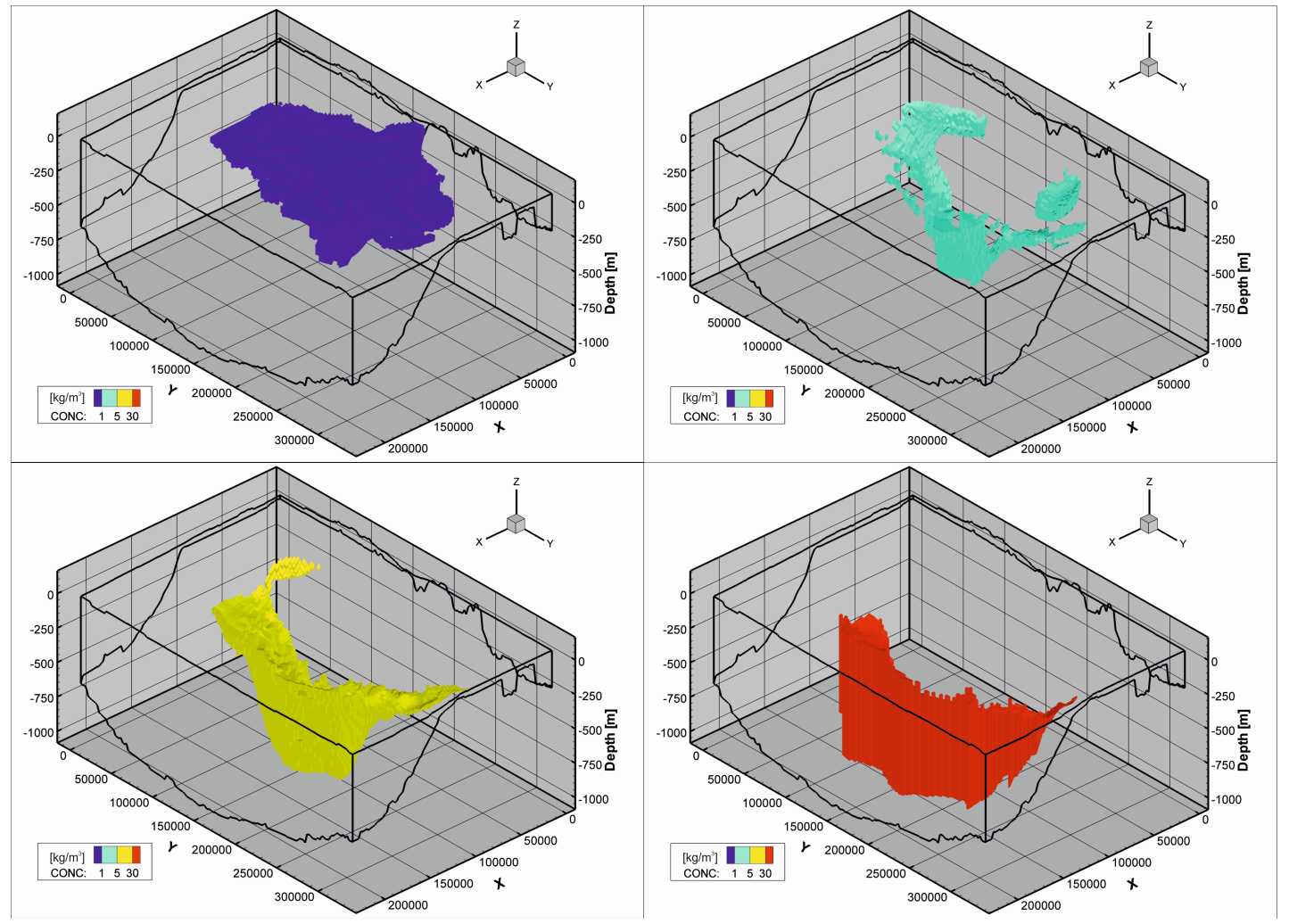

Figure 3. Spatial distribution of different groundwater types in the Nile Delta in 2010 (Concentration in $\left.\mathrm{kg} / \mathrm{m}^{3}\right)$.

It is clear from Table 2 that when only the influence of time is considered, the groundwater system becomes saltier. In Sc.1, the fresh groundwater volume decreases significantly by $31 \%$, while the light brackish, brackish and saline groundwater volumes have corresponding increases. In this case, because of the long simulation period, the changes in salinization volumes are large in comparison with the other scenarios. The significance of the results from this scenario is that they demonstrate that even without any SLR or increased groundwater extraction, the salinization of the NDA will continue. It was shown by [18] that the NDA has not reached equilibrium yet and that this complex groundwater system is characterized by slow hydrogeological variations that bring significant impacts only after a long period of time [24]. For this reason, this scenario, in fact, raises a warning alarm. It shows the need for the planning of continuous adaptation strategies that prevent the accumulation of inland 
groundwater salinization. There are a number of adaptation strategies that could be applied in the Nile Delta [10], for example, artificial recharge, the extraction of saline and brackish groundwater and the modification of pumping practices through the reduction of withdrawal rates or adequate relocation of groundwater extraction wells.

Table 2. Groundwater volume in $\times 10^{9} \mathrm{~m}^{3}$ in the Nile Delta aquifer (NDA) for the four groundwater types.

\begin{tabular}{|c|c|c|c|c|c|c|c|}
\hline $\begin{array}{c}\text { Groundwater } \\
\text { Types } \\
\mathrm{kg} / \mathrm{m}^{3}\end{array}$ & $\begin{array}{c}\text { Current } \\
2010 \\
\text { Reference }\end{array}$ & $\begin{array}{c}\text { Sc.1 } \\
2500 \\
\text { Long Run }\end{array}$ & $\begin{array}{c}\text { Sc. } 2 \\
2100 \\
\text { Extreme }\end{array}$ & $\begin{array}{c}\text { Sc.3 } \\
2100 \\
\text { Moderate }\end{array}$ & $\begin{array}{c}\text { Sc.4 } \\
2100 \\
\text { Restrictive }\end{array}$ & $\begin{array}{c}\text { Sc.5 } \\
2100 \\
\text { High Ext. }\end{array}$ & $\begin{array}{c}\text { Sc.6 } \\
2100 \\
\text { High SLR }\end{array}$ \\
\hline $\begin{array}{c}\text { Fresh water } \\
0-1\end{array}$ & 1290 & $\begin{array}{c}893 \\
-31 \%\end{array}$ & $\begin{array}{c}1049 \\
-18.7 \%\end{array}$ & $\begin{array}{c}1119 \\
-13.3 \%\end{array}$ & $\begin{array}{c}1190 \\
-7.7 \%\end{array}$ & $\begin{array}{c}1090 \\
-15.5 \%\end{array}$ & $\begin{array}{c}1147 \\
-11.1 \%\end{array}$ \\
\hline $\begin{array}{c}\text { Light brackish } \\
1-5\end{array}$ & 421 & $\begin{array}{r}436 \\
+3.6 \%\end{array}$ & $\begin{array}{r}434 \\
+3 \%\end{array}$ & $\begin{array}{r}432 \\
+2.7 \%\end{array}$ & $\begin{array}{r}431 \\
+2.4 \%\end{array}$ & $\begin{array}{r}433 \\
+2.9 \%\end{array}$ & $\begin{array}{r}432 \\
+2.8 \%\end{array}$ \\
\hline $\begin{array}{l}\text { Brackish } \\
5-30\end{array}$ & 829 & $\begin{array}{c}1051 \\
+26.8 \%\end{array}$ & $\begin{array}{r}900 \\
+8.5 \%\end{array}$ & $\begin{array}{r}888 \\
+7.1 \%\end{array}$ & $\begin{array}{r}886 \\
+6.9 \%\end{array}$ & $\begin{array}{r}894 \\
+7.9 \%\end{array}$ & $\begin{array}{r}890 \\
+7.4 \%\end{array}$ \\
\hline $\begin{array}{c}\text { Saline water } \\
>30\end{array}$ & 1513 & $\begin{array}{c}1734 \\
+14.6 \%\end{array}$ & $\begin{array}{r}1691 \\
+11.7 \%\end{array}$ & $\begin{array}{r}1600 \\
+5.7 \%\end{array}$ & $\begin{array}{r}1548 \\
+2.2 \%\end{array}$ & $\begin{array}{r}1631 \\
+7.7 \%\end{array}$ & $\begin{array}{r}1611 \\
+6.4 \%\end{array}$ \\
\hline
\end{tabular}

For Scenarios 2 to 6, the models were run up until 2100 with different SLR rates and/or groundwater extraction rates. For Sc.2 (extreme), the fresh water decreased significantly by $18.7 \%$ in 90 years, while the saline volume increased by approximately $12 \%$. These values are the highest among Scenarios 2 to 6 , because Sc. 2 shows the combined effect of an extreme SLR and groundwater extraction rate. Sc. 3 (moderate) shows modest values for fresh water volume loss $(-13.3 \%)$ and saline groundwater gain $(+5.7 \%)$.

Under very optimistic conditions, Sc.4 (Restrictive) has a small saline groundwater volume increase $(+2.2 \%)$. The fresh groundwater loss $(-7.7 \%)$ is the lowest among all other scenarios. To achieve this, however, very rigid control of groundwater extraction is necessary. Alternative, unconventional sources of water are required, possibly in combination with water saving and planting of crops that are more resistant to salt. Figure 4 shows the percent of change in different scenarios for the analysed groundwater types with respect to the 2010 baseline values.

In Sc.5 (high ext.), the fresh water volume decreases by about $15.5 \%$. That decrease is second in severity after Sc. 2 (extreme) with approximately 18.7\%. This is also demonstrated in Figures 5 and 6 below, indicating that the largest part of the decrease in volume comes from groundwater extraction, not SLR.

Table 2 shows a decline in fresh water in Sc.6 (high SLR) to about 11\%. This value is less than that in Sc. 5 discussed above, meaning that SLR has a smaller effect on the groundwater volumes in the whole NDA compared to groundwater extraction.

Figure 5 shows different cross-sections of the NDA for Scenarios 2, 5 and 6 . It is clear that the salinity front advances the most in Sc.2 (extreme) followed by Sc.5 (high ext.) and Sc.6 (SLR). The scenarios have the same ordering with respect to the size of the dispersion zone. 


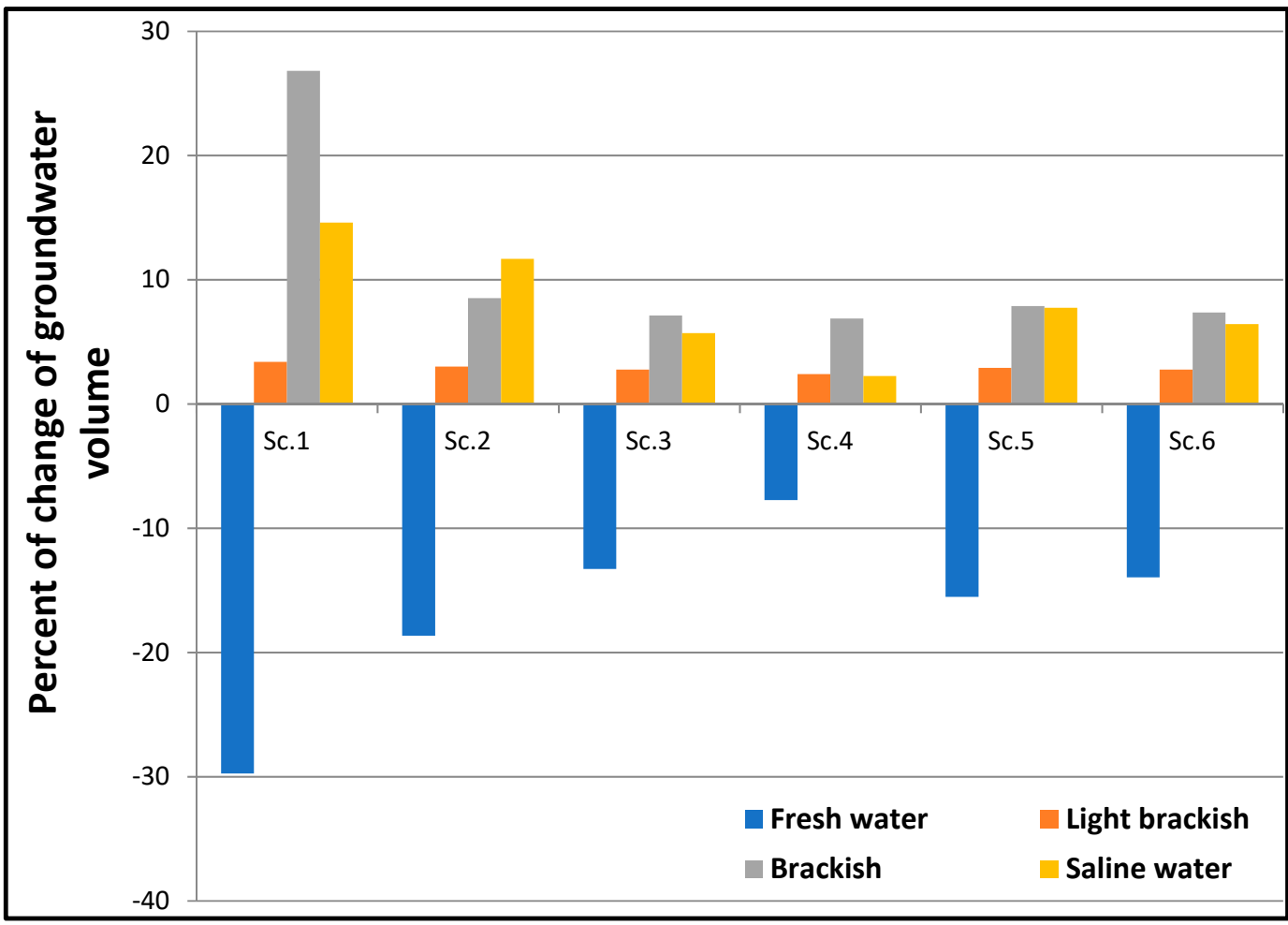

Figure 4. The percent of change of groundwater types in different scenarios, with respect to the 2010 baseline values.

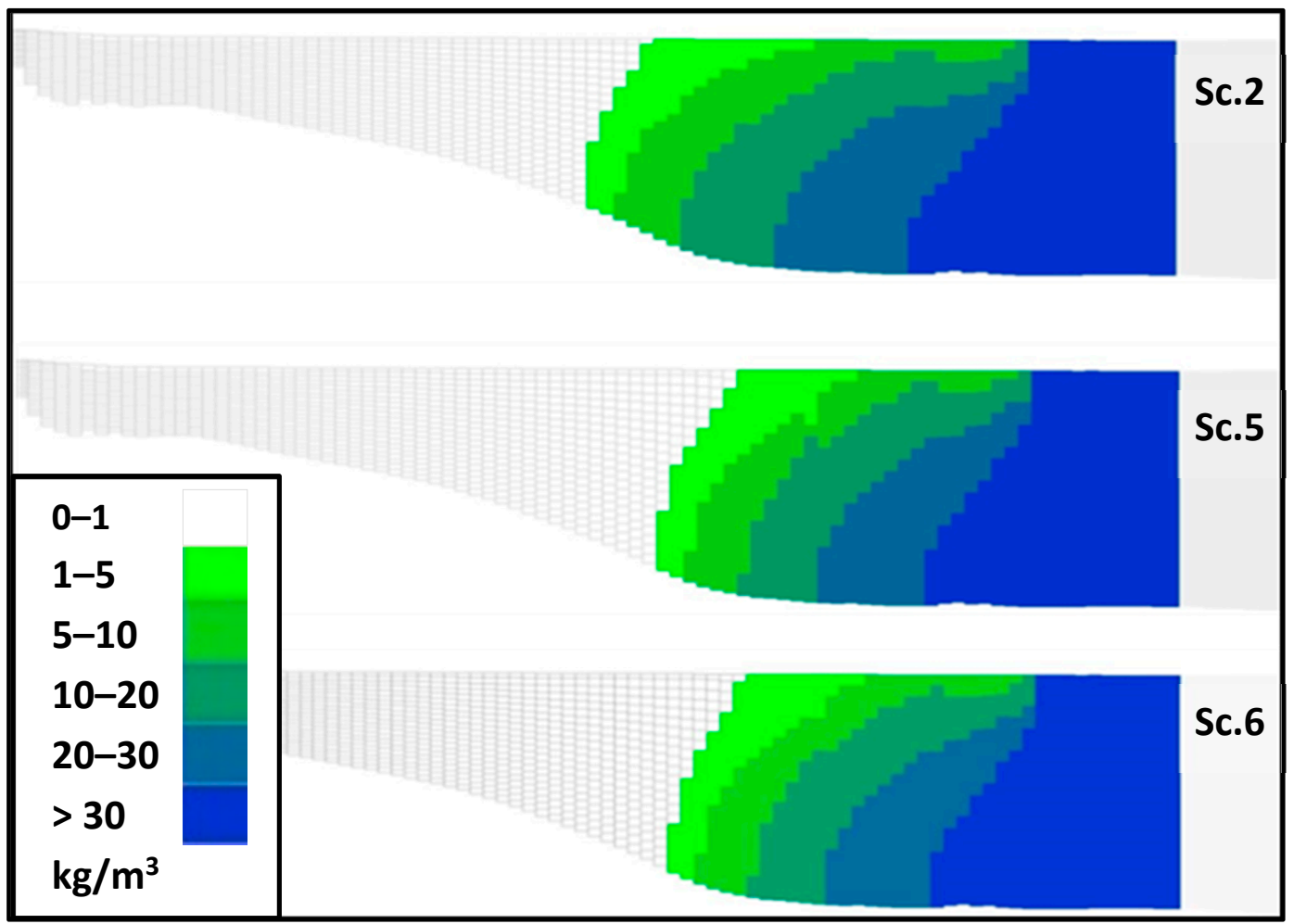

Figure 5. Cross-sections in the middle of the Nile Delta with different salinity distributions in different scenarios in the year 2100 . 


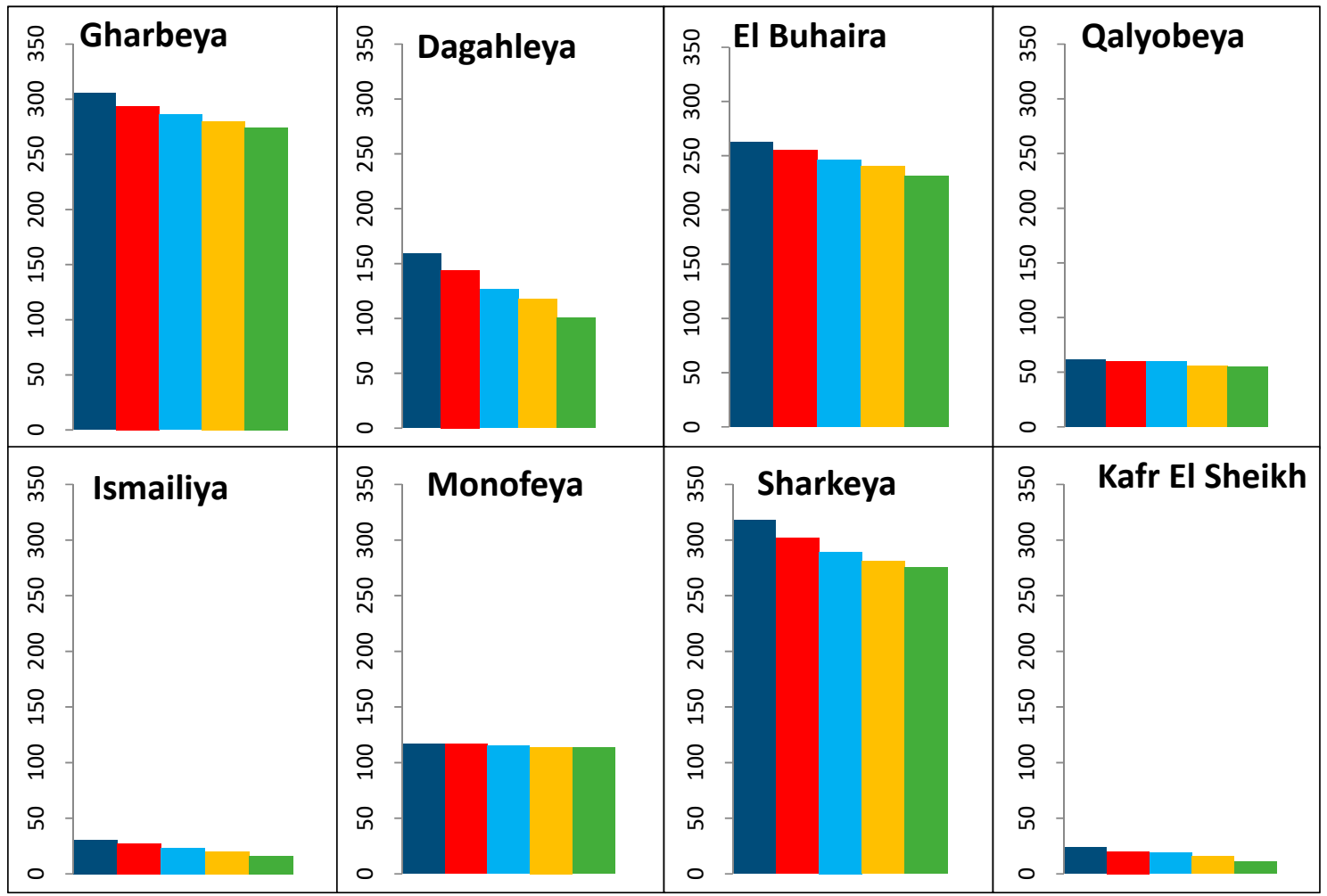

$\square$ Current $\square$ Sc.4 $\square$ Sc. 6 Sc.5 $\square$ Sc. 2

Figure 6. Block diagrams representing the fresh groundwater volume for different scenarios in selected governorates.

\subsection{The Nile Delta Governorates}

As stated in the study area section, the Nile Delta management system is organized into a number of governorates. The Egyptian governorates are administrative divisions. They are the second tier of the country's jurisdiction hierarchy, below the national government. Each governorate is administered by a governor, who is appointed by the President of Egypt [35]. The groundwater sector in Egypt is managed jointly by the MWRI and the governor in each governorate. Consequently, it is necessary to study salinization patterns with respect to each governorate, because each governorate has different hydrogeological parameters and more importantly, different agricultural and water resource management activities (groundwater extraction and irrigation) and thus, different groundwater type and salinization patterns.

Some of these governorates are coastal (e.g., Alexandria, Damietta), while others are far away from the zone where brackish and saline groundwater are present.

It is clear from Table 3 that El Buhaira, Gharbeya and Sharkeya have the highest freshwater volumes in all six scenarios (see Figure 1 for the locations of the governorates). On the other hand, coastal governorates have no fresh groundwater. Kafr El Sheikh and Ismailiya governorates have the lowest fresh groundwater volumes. The volume of fresh groundwater in each governorate is dependent on its location and distance from the coast, as well as the thickness of the aquifer, the governorate's area, the reclamation projects and the number of groundwater extraction wells. Here, again, it is clear that Sc.2 (extreme) has the highest impact of the governorates on salinization in 2100, followed by Sc.5 (high ext.) and Sc.6 (high SLR).

Figure 6 shows that for all scenarios, the fresh groundwater decreases at a lower rate in the Southern governorates, like Qalyobeya and Monofeya, compared to the Northern governorates, like Kafr El Sheikh. This is mainly because these governorates are far from the coastal zone. Meanwhile, the volume of fresh groundwater decreases at a high rate in the governorates Sharkeya and El Buhaira 
which suffer from the combined effect of excessive groundwater extraction and SLR. The analysis of the spatial distribution of salinity indicates that in these governorates, the Northern parts are already in a critical condition, while some continued groundwater extraction can still be allowed in the Southern regions. As we can see from Figure 6, Ismailiya governorate shows a significant drop of the (relatively small) fresh groundwater volume in all different scenarios. This governorate is already stressed by severe groundwater extractions, so future scenarios further intensify its criticality regarding available fresh water resources. In Dagahleya, the drop is also significant, although the absolute volume of fresh groundwater is larger. Coastal governorates (Kafr El Sheikh, Damietta and Alexandria) are very vulnerable to SLR. Damietta already has no fresh groundwater, while Kafr El Sheikh shows a severe reduction of fresh groundwater in the future in all scenarios.

Table 3. The fresh groundwater volume in $10^{9} \mathrm{~m}^{3}$ with respect to different scenarios in all governorates of the Nile Delta.

\begin{tabular}{|c|c|c|c|c|c|c|c|c|c|}
\hline Governorate & $\begin{array}{c}\text { Area } \\
10^{3} \mathrm{~km}^{2}\end{array}$ & $\begin{array}{c}\text { Extraction } \\
2010 \\
10^{6} \mathrm{~m}^{3} / \text { year }\end{array}$ & $\begin{array}{c}\text { Current } \\
2010\end{array}$ & $\begin{array}{c}\text { Sc.1 } \\
\text { Long } \\
\text { Run }\end{array}$ & $\begin{array}{c}\text { Sc.2 } \\
\text { Extreme }\end{array}$ & $\begin{array}{c}\text { Sc.3 } \\
\text { Moderate }\end{array}$ & $\begin{array}{c}\text { Sc.4 } \\
\text { Restrictive }\end{array}$ & $\begin{array}{c}\text { Sc.5 } \\
\text { High } \\
\text { ext. }\end{array}$ & $\begin{array}{l}\text { Sc.6 } \\
\text { High } \\
\text { SLR }\end{array}$ \\
\hline El-Buhaira & 10.130 & 1931 & 258 & 180 & 228 & 253 & 250 & 234 & 243 \\
\hline Daghleya & 3.5 & 114 & 160 & 62 & 100 & 135 & 143 & 118 & 127 \\
\hline Damietta & 1.029 & 362.5 & 0 & 0 & 0 & 0 & 0 & 0 & 0 \\
\hline Gharbeya & 1.942 & 291.7 & 306 & 200 & 274 & 289 & 294 & 279 & 286 \\
\hline Ismailiya & 2.10 & 163.8 & 31 & 8 & 16 & 26 & 28 & 20 & 24 \\
\hline $\begin{array}{l}\text { Kafr El } \\
\text { Sheikh }\end{array}$ & 3.437 & 0.9 & 24 & 0 & 11 & 19 & 20 & 16 & 18 \\
\hline Monofeya & 2.543 & 791.5 & 120 & 105 & 113 & 117 & 118 & 114 & 116 \\
\hline Qalyobeya & 1.124 & 408.2 & 66 & 51 & 54 & 61 & 63 & 56 & 60 \\
\hline Sharkeya & 4.18 & 681.5 & 318 & 210 & 276 & 295 & 302 & 281 & 290 \\
\hline Alexandria & 2.679 & 2.4 & 22 & 5 & 7 & 14 & 15 & 9 & 13 \\
\hline Portsaid & 1.351 & 154.2 & 57 & 96 & 45 & 50 & 51 & 46 & 49 \\
\hline
\end{tabular}

Figure 7 shows the distribution of different groundwater types for selected governorates in the current situation (2010) and in 2100 under Sc.2 (Extreme). The Monofeya governorate has no saline or brackish groundwater, while the coastal governorates, for example, Kafr El Sheikh and Damietta, contain mainly brackish and saline groundwater.

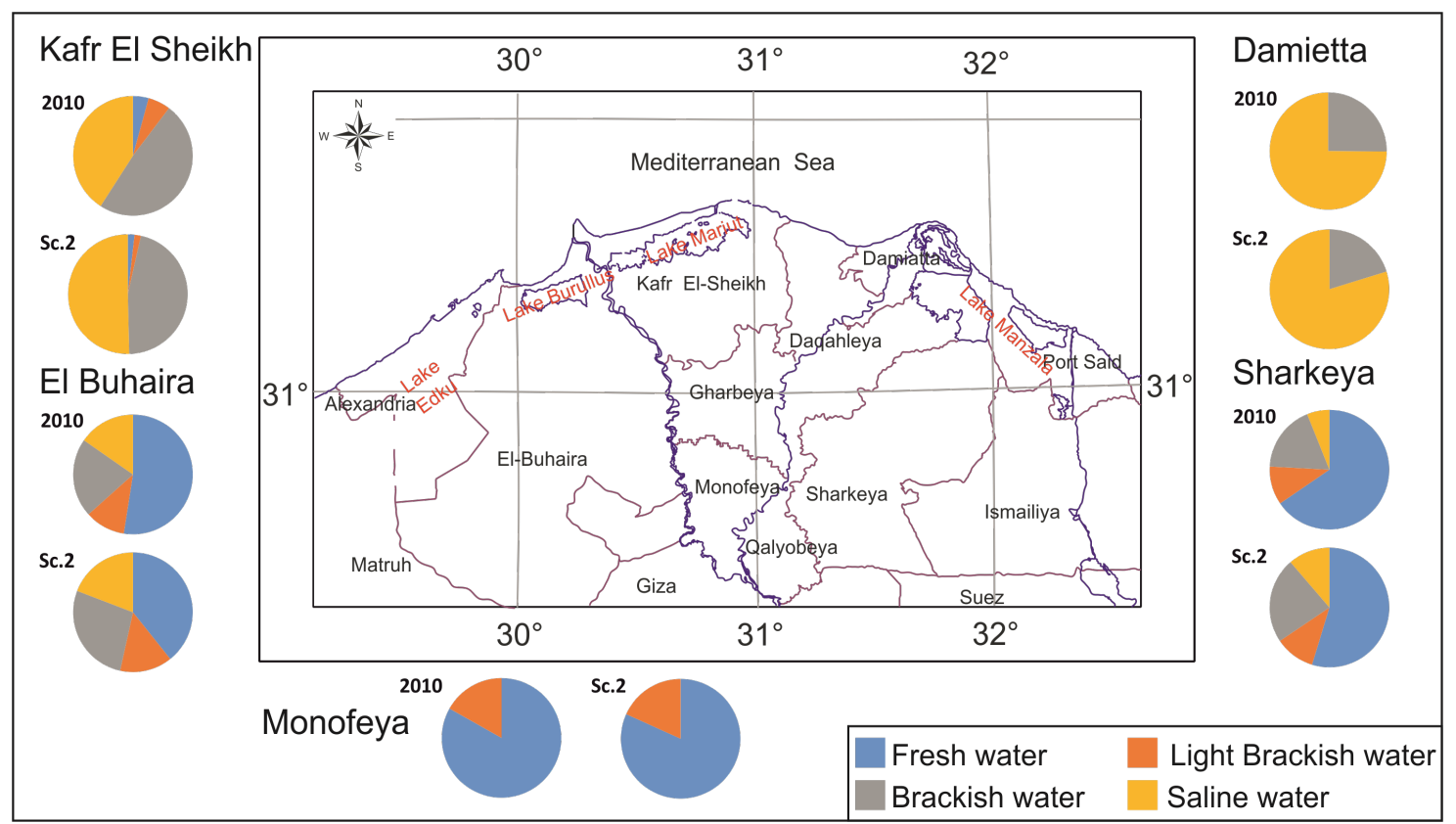

Figure 7. Proportional distribution of the different groundwater types for selected governorates in the current situation and under Sc.2 


\section{Conclusions and Recommendations}

This article presented an assessment of the impacts of sea-level rise (SLR) and groundwater extraction on saltwater intrusion (SWI) in the Nile Delta aquifer (NDA). Six scenarios of different combinations of SLR and groundwater extraction from the NDA were proposed. The analysis was carried out using a 3D variable-density groundwater flow model coupled with salt transport. The groundwater salinity conditions were analysed by using the change in volume for the four groundwater types in the whole Nile Delta and for each Nile Delta governorate separately. The results clearly demonstrate that the effect of groundwater extraction is more severe than the SLR. However, SLR is linked to climate change, which is beyond the direct control of the Egyptian government and imposes an extra burden on the groundwater system of the NDA, especially when it is combined with excessive groundwater extraction. Salinization will intensify in the future if adaptation and mitigation measures are not implemented.

It is recommended that groundwater extraction is banned in Northern coastal governorates that are very sensitive to SLR and groundwater extraction. No groundwater extraction or investment in agriculture should be made in the coastal governorates Ismailiya and Dagahleya due to their shortage in fresh groundwater. In the Southern governorates, like Qalyobeya and Monofeya, the groundwater extraction of fresh water can continue, as the results indicate that these governorates have only fresh and light brackish water and do not have any brackish or saline water in all future scenarios. Groundwater extraction can be allowed only in the Southern parts of the Sharkeya and El Buhaira governorates, because their Northern parts are already in a critical condition. Table 4 summarizes the recommended locations for future groundwater extraction in different governorates of the Nile Delta.

Table 4. A summary of the recommended groundwater extraction locations in the Nile Delta governorates.

\begin{tabular}{|c|c|c|}
\hline Governorate & Recommendation & Reason \\
\hline $\begin{array}{l}\text {-Coastal governorates } \\
\text { Kafr El Sheikh } \\
\text { Alexandria } \\
\text { Damietta } \\
\text { Port Said }\end{array}$ & $\begin{array}{l}\text { Ban groundwater extraction } \\
\text { Search for alternatives }\end{array}$ & $\begin{array}{l}\text {-Limited or no fresh groundwater } \\
\text {-Sensitive to SWI (saltwater intrusion) }\end{array}$ \\
\hline $\begin{array}{l}\text {-Middle governorates } \\
\text { El Buhaira } \\
\text { Gharbeya } \\
\text { Sharkeya }\end{array}$ & $\begin{array}{l}\text { Extraction } \\
\text { in the Southern region }\end{array}$ & $\begin{array}{l}\text {-Fresh water is decreasing rapidly } \\
\text {-Suffer from combined effects of excessive } \\
\text { groundwater extraction and SLR } \\
\text {-Have the highest fresh water volumes }\end{array}$ \\
\hline $\begin{array}{l}\text { Ismailiya } \\
\text { Dagahleya }\end{array}$ & $\begin{array}{l}\text { No groundwater extraction } \\
\text { No investment in agriculture that } \\
\text { relies on groundwater }\end{array}$ & $\begin{array}{l}\text {-A huge drop of fresh water volume } \\
\text { between different scenarios } \\
\text {-SWI and ext. that intensify the criticality of } \\
\text { its small fresh water volume }\end{array}$ \\
\hline $\begin{array}{l}\text {-Southern governorates } \\
\text { Qalyobeya } \\
\text { Monofeya }\end{array}$ & $\begin{array}{l}\text { Groundwater extraction } \\
\text { is recommended }\end{array}$ & $\begin{array}{l}\text {-Fresh water is decreasing slowly } \\
\text {-Far from SWI }\end{array}$ \\
\hline
\end{tabular}

For strategic planning of groundwater management in Egypt until 2100, it is recommended that future groundwater extraction distribution is adjusted. The vulnerability of governorates in terms of the available fresh groundwater volume (under stress) should be taken into consideration when designing future water management adaptation plans. Taking serious measures, such as closing illegal wells, implementing full control of new authorization permits for groundwater extraction in the NDA and giving strict fines for any violation of groundwater extraction regulations, will be required to reduce the salinization problem. Additionally, future innovations and technologies, such as waste water reuse, crop management and desalinization, should be actively pursued. Moreover, immediate initialization of development projects that could protect groundwater salinization is needed, for instance, desalination and rain harvesting projects in the Northern coastal region.

Finally, it should be recognized that salt water intrusion is a long-term process which may led to the future deterioration of fresh groundwater resources in the NDA, even beyond 2100. Sc.1 which runs 
until 2500 indicates that time alone can bring further saltwater intrusion into the NDA. If uncontrolled development of groundwater resources continues while control and adaptation measures are not taken into account, this valuable fresh groundwater resource will be impaired to an extent that negatively affects the overall socioeconomic development of the country.

Author Contributions: The study is part of a PhD research conducted by M.M., under supervision of A.J., G.O.E. and S.U. The paper is conducted as a joint effort of all authors. Conceptualization, M.M., A.J. and G.O.E.; Methodology, M.M., A.J. and G.O.E.; Software, M.M.; Validation, M.M.; Formal Analysis, M.M., A.J. and G.O.E.; Resources, M.M.; Data Curation, M.M.; Writing-Original Draft Preparation, M.M.; Writing-Review \& Editing, M.M., A.J. and G.O.E.; Supervision, A.J., G.O.E. and S.U.

Funding: This work has been supported financially by IHE Delft Institute for water education, Delft, The Netherlands.

Acknowledgments: The authors would like to thank the Ministry of Water Resources and Irrigation in Egypt for providing us with data.

Conflicts of Interest: The authors declare no conflict of interest.

\section{References}

1. EGSA. Egyptian General Survey and Mining: Topographical Map cover Nile Delta, Scale 1:2 000 000; Egyptian General Survey and Mining (Publishing Center): Cairo, Egypt, 1997.

2. SADS2030-Sustainable Agricultural Development Strategy, 1st ed.; Ministry of Agriculture and Land Reclamation of Egypt: Cairo, Egypt, 2009; p. 197.

3. Farid, M.S.M. Nile Delta Groundwater Study. Master's Thesis, Cairo University, Cairo, Egypt, 1980.

4. Mabrouk, M.B.; Jonoski, A.; Solomatine, D.; Uhlenbrook, S. A Review of Seawater Intrusion in the Nile Delta Groundwater System-The basis for Assessing Impacts due to Climate Changes, Sea Level Rise and Water Resources Development. Nile Water Sci. Eng. J. 2017, 10, 46-61.

5. Diab, M.S.; Dahab, K.; El Fakharany, M. Impacts of the paleohydrological conditions on the groundwater quality in the northern part of Nile Delta, The geological society of Egypt. Geol. J. B 1997, 4112, 779-795.

6. Custodio, E. Aquifer overexploitation: What does it mean? Hydrogeol. J. 2002, 10, 254-277. [CrossRef]

7. Yihdego, Y.; Panda, S. Studies on Nature and Properties of Salinity across Globe with a View to its Management-A Review. Glob. J. Hum. Soc. Sci. Res. 2017, 17, 31-37.

8. Oude Essink, G.H.P.; Van Baaren, E.S.; De Louw, P.G.B. Effects of climate change on coastal groundwater systems, a modeling study in the Netherlands. Water Resour. Res. J. 2010, 46, W00F04. [CrossRef]

9. Yihdego, Y.; Al-Weshah, R.A. Assessment and prediction of saline sea water transport in groundwater using 3-D numerical modelling. Environ. Processes J. 2016, 4, 49-73. [CrossRef]

10. Gorelick, S.M.; Zheng, C. Global change and the groundwater management challenge. Water Resour. Res. J. 2015, 51, 3031-3051. [CrossRef]

11. Ojha, L.; Wilhelm, M.B.; Murchie, S.L.; McEwen, A.S.; Wray, J.J.; Hanley, J.; Massé, M.; Chojnacki, M. Spectral evidence for hydrated salts in recurring slope linear on Mars. Nat. Geosci. J. 2015, 8, 829. [CrossRef]

12. Mahmoodzadeh, D.; Ketabchi, H.; Ataie-Ashtiani, B.; Simmons, C.T. Conceptualization of a fresh groundwater lens influenced by climate change, A modelling study of an arid-region island in the Persian Gulf, Iran. Hydrol. J. 2014, 519, 399-413. [CrossRef]

13. Ketabchi, H.; Mahmoodzadeh, D.; Ataie-Ashtiani, B.; Simmons, C.T. Sea-level rise impacts on seawater intrusion in coastal aquifers: Review and integration. Hydrol. J. 2016. [CrossRef]

14. Nofall, E.R.; Fekry, A.F.; El-Didy, S.M. Adaptation to the Impact of Sea Level Rise in the Nile Delta Coastal zone, Egypt. Am. Sci. J. 2014, 10, 17-29.

15. Sefelnasr, A.; Sheriff, M.M. Impacts of Seawater Rise on Seawater Intrusion in the Nile Delta Aquifer, Egypt. Groundw. J. 2014, 52, 264-276. [CrossRef] [PubMed]

16. Sherif, M.M.; Sefelnasr, A.; Javadi, A. Incorporating the concept of Equivalent Fresh water Head in Successive Horizontal Simulations of Seawater Intrusion in the Nile Delta aquifer, Egypt. Hydrol. J. 2012, 464-465, 186-198. [CrossRef]

17. Abdelaty, I.M.; Abd-Elhamid, H.F.; Fahmy, M.F.; Abdelaal, G.M. Investigation of some potential parameters and its impacts on saltwater intrusion in Nile Delta aquifer. J. Eng. Sci. 2014, 42, 931-955. [CrossRef] 
18. Mabrouk, M.B.; Jonoski, A.; Oude Essink, G.H.P.; Uhlenbrook, S. Delineating the fresh-saline groundwater distribution in the Nile Delta using a 3D variable-density groundwater flow model coupled with salt transport. Hydrol. J. Reg. Stud. 2018. under review.

19. Field, C.B.; Barros, V.R.; Dokken, D.J.; Mach, K.J.; Mastrandrea, M.D.; Bilir, T.E.; Chatterjee, M.; Ebi, K.L.; Estrada, Y.O.; Genova, R.C.; et al. Climate Change 2014: Impacts, Adaptation, and Vulnerability. Part A: Global and Sectoral Aspects; Contribution of Working Group II to the Fifth Assessment Report of the Intergovernmental Panel on Climate Change; IPCC: Geneva, Switzerland, 2014.

20. Delsman, J.R.; Hu-a-ng, K.R.M.; Vos, P.C.C.; De Louw, P.G.B.; Oude Essink, G.H.P.; Stuyfzand, P.J.; Bierkens, M.F.P. Paleo-modeling of coastal saltwater intrusion during the Holocene, An application to the Netherlands. Hydrol. Earth Syst. Sci. J. 2014, 18, 3891-3905. [CrossRef]

21. Sestini, G. Nile Delta: A review of depositional environments and geological history. Geol. Soc. Lond. Spec. Publ. 1989, 41, 99-127. [CrossRef]

22. Morsy, W.S. Environmental Management to Groundwater Resources for Nile Delta Region. Ph.D. Thesis, Faculty. of Engineering, Cairo University, Cairo, Egypt, 2009.

23. Van Engelen, J.; Oude Essink, G.H.P.; Kooi, H.; Bierkens, M.F.P. On the origins of hypersaline groundwater in the Nile Delta aquifer. Hydrol. J. 2018, 560, 301-317. [CrossRef]

24. Bear, J. Hydraulics of Groundwater; McGraw-Hill Book Company: New York, NY, USA, 1979; p. 592, ISBN 0-486-45355.

25. CAPMAS. The Central Authority for Public Mobilization and Statistics, Egypt, Egypt in Numbers; Ministry of Communication and Information Technology (Publishing Center): Cairo, Egypt, 2010.

26. United Nations, Department of Economic and Social Affairs, Population Division. World Population Prospects: The 2015 Revision, Key Findings and Advance Tables, United Nations, New York 2015, Working Paper No. ESA/P/WP.241. Available online: https://esa.un.org/unpd/wpp/publications/files/key_ findings_wpp_2015.pdf (accessed on 15 November 2018).

27. Yihdego, Y.; Khalil, A.; Salem, H.S. Nile Rivers Basin Dispute: Perspectives of the Grand Ethiopian Renaissance Dam (GERD). Hum. Soc. Sci. Res. J. 2017, 17, 1-21.

28. Solomon, S.; Qin, D.; Manning, M.; Chen, Z.; Marquis, M.; Averyt, K.B.; Tignor, M.; Miller, H.L. Contribution of Working Group I to the Fourth Assessment Report of the Intergovernmental Panel on Climate Change; Cambridge University Press: Cambridge, UK; New York, NY, USA, 2007.

29. DeConto, R.M.; Pollard, D. Contribution of Antarctica to past and future sea-level rise. Nature 2016, 531, 591-597. [CrossRef] [PubMed]

30. Jevrejeva, S.; Grinsted, A.; Moore, J.C. Upper limit for sea level projections by 2100. Environ. Res. Lett. 2014, 9, 104008. [CrossRef]

31. Le Bars, D.; Drijfhout, S.; de Vries, H. A high-end sea level rise probabilistic projection including rapid Antarctic ice sheet mass loss. Environ. Res. Lett. 2017, 12, 044013. [CrossRef]

32. Meisler, H.; Leahy, P.P.; Knobel, L.L. Effect of Eustatic Sea-Level Changes on Saltwater-Fresh Water in the Northern Atlantic Coastal Plain; USGS Water Supply Paper; US Government Printing Office: Alexandra, VA, USA, 1984; Volume 2255, p. 34.

33. Larsen, F.; Tran, L.T.L.V.; Van Hoang, H.; Tran, L.T.L.V.; Christiansen, A.V.; Pham, N.Q. Groundwater salinity influenced by Holocene seawater trapped in incised valleys in the Red River delta plain. Nat. Geosci. 2017, 10, 376-381. [CrossRef]

34. Lide, D.R. (Ed.) CRC Handbook of Chemistry and Physics, 86th ed.; CRC Press: Boca Raton, FL, USA, 2015; p. 5585, ISBN 0-8493-0486-5.

35. Metz, H.C. (Ed.) Egypt: A Country Study; GPO for the Library of Congress: Washington, DC, USA, 1990.

(C) 2018 by the authors. Licensee MDPI, Basel, Switzerland. This article is an open access article distributed under the terms and conditions of the Creative Commons Attribution (CC BY) license (http:/ / creativecommons.org/licenses/by/4.0/). 